European Journal of Accounting, Auditing and Finance Research

Vol.8, No. 7, pp.80-96, July 2020

Published by ECRTD-UK

Print ISSN: 2053-4086(Print), Online ISSN: 2053-4094(Online)

\title{
ORGANIZATIONAL STRUCTURE AND CORPORATE INVESTMENT DECISIONS AMONG SELECTED LISTED MANUFACTURING FIRMS IN NIGERIA
}

\author{
Yisa. A. Adeniji, \\ Department Of Accountancy, Yaba College of Technology, Yaba, Lagos State, \\ Nigeria. \\ adeniji.adeniyi@gmail.com
}

\begin{abstract}
Globally, the rate at which auditors are been sanctioned for negligence and even outright collusion on financial statement misrepresentation continues to be on the increase. This situation remains unabated despite the establishment of various statutory regulations, standards and guidelines. Yet, investors both private, corporate and institutional continues to rely on the audited financial statement with adverse conquences resulting to substantial financial loses. This situation now calls for additional sources of information that would enhance the quality of corporate investment decision. This study investigated the impact of organizational structure on corporate investment decisions in selected listed manufacturing firms in Nigeria. The study adopted survey research designs with a population of 54 listed manufacturing firms in Nigeria. Purposive sampling technique was used to select 510 respondents from a sample frame of 34 companies. A structured questionnaire was used to collect data validated using Cronbach Alpha with Coefficient ranging from 0.772 to 0.907 with $97.2 \%$ response rate. The data was analyzed and validated using descriptive and inferential statistics. The study found organizational structure had significant influence on corporate investment decisions $\left(R^{2}=0.361, \beta=0.674, t(484)=\right.$ $16.522 ; p<0.05)$. The study concluded that organizational structure influences corporate investment decisions for different stakeholders in selected listed manufacturing companies in Nigeria. The study recommended that investors and decision makers alike should consider and monitor the adopted organizational structure in addition to the audited financial statement when embarking on corporate investment decisions.
\end{abstract}

KEYWORDS: Corporate Investment Decision, Listed manufacturing firms, Organizational structure,

\section{INTRODUCTION}

The contemporary business globally has witnessed a rapid expansion in business transactions, economic growth and development based on the investors' perceptions of investment returns and wealth maximization. Deciding on what to do towards achieving the organizational goal is a core duty of a manager. On a regular basis operating managers whether at the top, middle or low level, are usually confronted with several issues such as the nature of product to produce and sell, the methods of production, outsourcing decision, making the product in-house or sub-contracting, appropriate selling prices, market and marketing research decisions, acceptance of an extra sales order decisions and optimal allocation of available resources. Corporate investment decisions are therefore regarded as challenging and strategic in nature due to the fact that different options and 
European Journal of Accounting, Auditing and Finance Research

Vol.8, No. 7, pp.80-96, July 2020

Published by ECRTD-UK

Print ISSN: 2053-4086(Print), Online ISSN: 2053-4094(Online)

numerous amount of variables (both quantitative and qualitative) are involved and very few will be considered relevant. Corporate investment decision entails a huge outlay of capital, choosing from among at least two alternatives. From a cursory observation, corporate investment decision is yet to be given a holistic attention it deserves. Zarnowitz (1992) observed that the level of corporate investment decisions can be used to gauge the performance level of any economy from the perspectives of macro and micro. From the macro perspective in a regular business circle, investment decision account for the majority of the volatility in the Gross Domestic Product (GDP) dynamics and their magnitude serves as a significant leading indicator of economic performance. From the micro perspective, they are crucial for the growth of individual companies, increasing their efficiency by reducing units costs (Zarnowitz, 1992). The key performance indicator of any enterprise is the way and manner in which management invest the available resources. This position is premised on the fact that, appropriate investment decisions will increase the stakeholder's wealth. Such decisions may include the channeling of available funds to acquire equipment (acquisition of new assets or replacement decision), make in house or outsource, or research and development of new project. A decision maker must however ensure an optimal balance between an immediate cash outflow and the future cash earnings ability of the project. The research investigating the process of investment decisions at the company level has generally shown that it is a multi-criteria process (Enoma \& Mustapha, 2010) taking into account numerous factors. These factors include not only economic and risk factors but also the political and social environment together with government regulations (Enoma \& Mustapha, 2010). Although, the effects of these factors vary significantly among individual companies (Bialowolski \& NeziakBialavolska, 2014) yet researchers generally ignored the impact of organizational structure on investment decisions.

\section{Statement of the problem}

Generally, available economic literature indicates a strong relationship between corporate investment decisions and the Gross Domestic Product (GDP) of any country. This relationship also impact significantly on the economic growth and development of a nation. By implication, if there is an increase in the level of corporate investment in a particular environment, then there is the likelihood of high rate of employment, increase in national income, rise in gross domestic product (GDP) and improved quality of living standards. At the moment, Nigeria's situation is precarious due to high level of unemployment, upsurge in crime rate (such as kidnapping, armed robbery, internet fraud, yahoo plus, illegal bunkering, banditry), high rate of inflation and feeling of hopelessness among the citizenry (Okon \& Osesie, 2017).Invariably, all the aforementioned factors are traceable to the general decline in the level of corporate investment in the country.

Nigeria is currently facing a decline in the level of corporate investment. This is due to the general decline in the level of foreign direct investments, general apathy among local investors due to low rate of return, sudden collapse of several business establishments (Bank PHB Plc, Oceanic Bank, Intercontinental Bank, Leyland, Skye Bank, and Diamond Bank), among others. The recent relocation of some multinational organizations (such as Dunlop, Michellin, and Siemens) from Nigeria to other neighboring countries like Ghana, Togo and Republic of Benin are also a major factor reducing investment opportunities in the country. Furthermore, some local investors now prefer to invest their resources outside the country due to factors such as power, inconsistency in 
European Journal of Accounting, Auditing and Finance Research

Vol.8, No. 7, pp.80-96, July 2020

Published by ECRTD-UK

Print ISSN: 2053-4086(Print), Online ISSN: 2053-4094(Online)

government policies, level of political instability among others. However, the most significant factor negating corporate investment decisions in Nigeria and also globally may be attributed to the reliance on the audited financial statement for investment decision. As a result of the problem associated with agency cost and information asymmetry, directors may naturally have the temptation for window-dressing the financial statement of any organization. This is because the agent (management or directors) who are in possession of the financial information of the enterprise will naturally prefer to present a favourable picture of the business to the principal (shareholders) in other to attract a higher benefit. To guarantee the accuracy of the prepared financial statement by the management of the enterprise, section 357 of the Companies and Allied Act, 2004 (Cap C20 LFN) stipulates that members of every limited liability companies must appoint a statutory auditor on an annual basis. The statutory auditor is to act in that position from the conclusion of the annual general meeting (AGM), when appointed to the conclusion of the next (AGM). In addition, S.361 of CAMA, 2004 also stipulates that the auditor remuneration must be determined by whoever appoint the auditor. The objective of the law in ensuring that the statutory auditor is appointed and remunerated by the shareholders (principal) is to guarantee the independence of the auditor. However, despite the perceived auditor's independence, the primary responsibility is to express a professional opinion on whether the financial statement prepared and presented by the agent (management) shows a true and fair view. On closer observation, it is logical to posit that what is true to the auditor may not be fair to the public, and what is fair to the public may not be true to the auditor and the other parties concerned. In addition, corporate governance failure are extremely difficult to detect by the statutory auditor. Although, it is generally argued that the appointment of the statutory auditor is in the best interest of the shareholders (principals), management (agents), and all the other third parties (Watts \& Zuo, 2011).

Furthermore, auditor's job is embedded with certain associated risk known as audit risk. Audit risk represents a situation where the auditor expresses an inappropriate audit opinion on the financial statement of an organization. Auditor may express an unqualified audit opinion instead of a qualified audit opinion. The audit risk can be further classified into three components such as the control risk, detection risk and the inherent risk. The work of the auditor is also under the influence of both internal and external business risk. It is generally believed that audit risk may not be eliminated completely but can only be minimize through adequate quality control assurance measures. Therefore, whenever an investor picks up a copy of the audited financial statement of any establishment, is the investor aware of the aforementioned challenges associated with the audited statement? For decades, many organizations globally collapsed as a result of poor investment decisions occasioned by heavy reliance on audited financial statements and failure to address the problem of lack of corporate governance by board of directors (Nguyen, 2011). The manipulations of accounting figures by reporting companies was due to the need to present an exceptional result that will attract higher compensation to the management (Asogwa, 2009; Healy \& Palepu, 2003). This practice of financial report misrepresentation commonly leads to loss of credibility, integrity and confidence in accounting information and the earnings become questionable (Akintoye, Jaiyeoba, Ajibade, Olayinka \& Kwarbai, 2016). This situation further increased the current debate between voluntary and compulsory disclosure of information as contained in the financial statement of an organization. 
European Journal of Accounting, Auditing and Finance Research

Vol.8, No. 7, pp.80-96, July 2020

Published by ECRTD-UK

Print ISSN: 2053-4086(Print), Online ISSN: 2053-4094(Online)

For decades, researchers globally have been investigating the various factors influencing investment decisions among individuals and institutional investors with little or no effort in the area of organizational structure. For example, among, the factors investigated on investment decisions includes but not limited to: corporate risk and dividend (Efni, 2018) new product development (Zheng \& Wang. 2018); financial reporting practice (Kapellas \& Siougle, 2017); financial statement analysis (Vestline, Kule \& Mbabazize, 2016); corporategovernance (Bistrova, Lace \& Travonaviene, 2015); SMEs (Sungun, 2015); capital structure (Arafat, Warokka \& Suryasaputa, 2014); risk factor (Viclics, 2013) and price earnings ratios (Pietrovito, 2010). In Nigeria reseachers contributing to the discourse on corporate investment decisions are also focusing on: risk impact (Farayi, 2015); Monetary policy (Ibi, Offiong \& Udofia, 2015); financial statements (Anaja \& Onoja, 2015, Patrick, Tavershina \& Eje, 2017); capital budgesting (Obid \& Adeyemo, 2014); capital market (Tomola, 2013) and modern portfolio theory (Omisore, Yusuff \& Nwufo, 2012) among others but not related to organizational structure. Conversely, those who researched into organizational structure analysis (Tasnim, 2018); new product development (Bai, Feng, Vive \& Feng, 2017); responsibility accounting (Ritika, 2015, Mojgan 2012); and organizational performance (Oke \& Fadeyi, 2015) but not on investment decisions. The objective of this paper therefore, is to investigate the impact of the adopted organizational structure on corporate investment decisions among selected listed manufacturing firms in Nigeria

\section{Research Hypothesis}

Ho: Organizational Structure does not have significant effect on corporate investment decisions selected listed manufacturing firms in Nigeria.

\section{LITERATURE REVIEW}

\section{Corporate Investment Decisions}

Corporate investment decisions refers to a financial commitments that usually last for several years with long term consequences such as returns, risk, uncertainty and time value of money. The sum of money involved in corporate investments is relatively huge while the time scale over which expected benefit will be received is relatively long. The entire nature of a business and its direction are majorly influenced by corporate investment decisions. Therefore, an inappropriate investment decisions may have a very serious negative consequences on the organization. An important part of a performance manager's job is to provide information which will assist the making of decisions concerning the investment of capital funds. Notable examples of corporate investment decisions are replacement decisions (decision to replace a semi- automatic machine with a fully automated machine); investment for expansion; investment for product improvement or cost reduction and new ventures. Efni (2018) observed that investment decision is one of the factors that affect the corporate value, in which the investment decision is associated with. Notable other components are the allocation of funds and sources of financing (which come from inside and outside the company) as well as the use of funds for the short-term and long-term purposes. The goal of the company's investment decision is to maximize the Net Present Value (NPV) of the organization as positive NPV would increase the real assets (Husnan, 2000). Efni (2017) postulated that investment decisions had a significant direct impact on the corporate value. By implication, right investment decision will improve the corporate value of an organization. However by right 
European Journal of Accounting, Auditing and Finance Research

Vol.8, No. 7, pp.80-96, July 2020

Published by ECRTD-UK

Print ISSN: 2053-4086(Print), Online ISSN: 2053-4094(Online)

investment, it is assumed that a good investment decision is such that can generate a positive NPV, meaning that the investment decision can generate a higher return than the weighted average cost of capital of the company.

Using the viewpoint of financial management, the company's goal is to maximize shareholder's prosperity. However, increase in shareholder's prosperity is only achievable through the increase in the company's value. To increase the company's value, management must choose the right type of investment. As a result of the current stiff competition among medium or large establishment, the survival of any organization depends strictly on strategic decisions by top managers (Vestine, Kule \& Mbabazize, 2016). Traditionally, every human being needs information in order to make the right decision, at the right time. Without correct information, any decisions made by decision makers may impede the growth of that organization (Vestine, Kule \& Mbabazize, 2016). The management of an enterprise is dependent on accounting information for taking various strategic decisions and responsibility accounting provides such information. According to Duru (2012), there is the general belief that published financial statements have failed in its responsibility to provide credible information for investors and other users of financial statements. It was observed that the roles of financial statement on investment decision making of financial institutions in Nigeria has some problems to both investors and managers of business organizations who are either not aware of the importance of interdependence relationship that exist between investors and financial organizations (Anaja \& Onoja, 2015).

Anaja and Onoja (2015) opined that in Nigeria, it has become common practice by financial institutions to adopt creative accounting in anticipation of sourcing for equity capital from the markets and other establishments. Naturally, this approach in financial reporting process often leads to over valuation of assets and company's net worth in the views of prospective shareholders and other stakeholders. Okoye and Alao (2008) attributed creative accounting to the transformation of financial accounting figures from what they actually are to a position where preparers decide by taking advantage of the existing rules and or ignoring some or all of them. Central and Eastern European companies quite often have major owner in the capital structure who is also being very active in the routine company management (Lace, Bistrova \& Kozhovkis, 2013). Besides, the creative accounting practices tend to emerge on the corporate landscape of Central and Eastern European countries quite often (Bistrova, Lace \& Tvaronavociene, 2015). Therefore, majority of investors globally appreciate very good information disclosure, which could positively influence investment decision and by extension the performance of the company in the long-term. Investment decisions significantly affect the intensity of overall economic activity and growth. In general, changes in size, structure and purpose of investment may indicate forthcoming conjuncture changes, but also the long-term developmental characteristics of the economy (Pevic \& Durkin, 2015).

\section{Organizational Structure}

According to Bai, Fang, Yue and Feng (2017) organizational structure refers to the formal arrangement of work-roles in an organization and the mechanism of management and integration of work which includes inter organizational activities designed towards achieving the business goals. A business organization is made up of people and resources to accomplish a certain 
European Journal of Accounting, Auditing and Finance Research

Vol.8, No. 7, pp.80-96, July 2020

Published by ECRTD-UK

Print ISSN: 2053-4086(Print), Online ISSN: 2053-4094(Online)

economic goal. It is the organizational planning that determines how the elements work together to achieve the overall goals of the organizations (Mojgan, 2012). The lines of authority should be fully defined before the responsibility system is implemented. This is because, a sound organizational structure with clear outlines of authority and responsibility relationships is a prerequisite for establishing a successful responsibility accounting system (Ritika, 2015). Based on the current business development throughout the world, organizations need to adopt new technologies along with different strategies for the attainment of the organizational objectives. Today's business must therefore change its structure with new methodology like centrifugal where decisions making authority is delegated from higher administration units to lower levels, thereby increasing the importance of responsibility accounting in business (Allahverdi, 2014).

Responsibility accounting system must be so designed as to suit the adopted structure of the organization, when the powers and responsibilities are stated in clear terms. There will appear a level of management structure and each will make a share of responsibility within, which individuals can make their own decisions. However, every business organization must therefore adopt a management structure with individual managers given responsibility for a particular aspect of operations or activity. The operations or activity for which they are responsible can be regarded as a responsibility centre. Quanyen and Yezhauang (2013) observed that the structure of an organization gives it the shape to carry out its purpose in the business environment. Marthwelli (2001) however, argued that the type of organization's structure adopted by a firm will depend on the nature of the particular organization in question.

The huge tasks associated with a business enterprise necessitated the need to divide enterprise into different independent unit with appropriate authority and responsibility (Gadave, 2017). However, the degree of decentralization is greatest when a higher number of decisions are made lower the management hierarchy. In addition, more important decisions made at lower levels and the less checking required on the decisions. Generally, the benefits associated with decentralization will include: improved strategic decision making; increased flexibility and reduced communication problem; may eliminate uneconomic activities; increase motivation of divisional management and better training at an earlier stage in a manager's career and at a lower level. Rani and Rani (2015) observed that the size of organization determines whether the structure of it should be centralized or decentralized along with defining responsibility accounting system. This position implies that, it is necessary in terms of delegation of responsibilities and authorities to manager for the purpose of planning and controlling the business activities. An organization is characterized to be bureaucratic when it has a hierarchy where tasks flow downward and accountability flows upward, clear division of labour, well-written rules and impersonality in the positions held in the organization (Tasnim, 2018).

\section{Empirical Review}

Maduenyi, Oke and Ajagbe (2015) examined the effect of organizational structure on organizational performance using exploratory research design. Through secondary data analysis, the researcher posited that a strong relationship exist between organizational performance and organizational structure. As a result, it is mandatory for any organization to have a defined structure, with clear division of work among different category of workers. In addition, the 
European Journal of Accounting, Auditing and Finance Research

Vol.8, No. 7, pp.80-96, July 2020

Published by ECRTD-UK

Print ISSN: 2053-4086(Print), Online ISSN: 2053-4094(Online)

structure must be designed towards achieving the corporate objectives of the organization. Owino, et al.,(2016) claimed that responsibility accounting is an administrative accounting method which deals with costs and revenues performance, and also used in measuring the results of all responsibility centres where performance of the managers is evaluated based on the things which are under their control. They conducted cross-sectional survey in order to find out if the concepts of responsibility accounting are being applied among Ugandan Public Universities. Their findings clearly indicate that responsibility accounting follows hierarchal patterns.

Zheng and Wang (2018) embarked on a study designed to investigate the impact of the previously acquired knowledge of an enterprise on the development of new product. To achieve this objective, the researcher, constructed a stackelberg game model using secondary data among selected manufacturing companies. It was discovered that knowledge spillover from previous product development influences investment decision relating to the development of new product. Although it is logical to conclude that knowledge resources is a qualitative aspect of responsibility accounting, the study did not mention responsibility accounting in any way. Chokeli (2015) examined the impact of the organizational design in evaluating the company's success in Georgia. Using triangulation research design, questionnaire was used to obtain data from forty-eight (48) companies while face-to-face interview were conducted on the staff of twenty (20) companies. Through descriptive analysis, findings reveal that legal barriers, taxes, currency variability, unstable environment and management are key factors influencing the success or failure of any organization. In addition, the effectiveness of any establishment will be measured through, strategic vision and goals, organizational structure, personnel, strategy, organizational culture, technology and leadership style.

Fakir, Islam and Miah (2014) investigated the impact of adopting responsibility accounting among the garment manufacturer in Bangladesh. The researchers adopted survey research design utilizing non-probabilistic sampling to circulate the structured questionnaire in obtaining the required primary data. Descriptive and inferential statistics revealed that the adoption of responsibility accounting is satisfactory in all the listed garment industries investigated. Tasnim (2018) investigated the impact of organizational structure and analysis on the smooth operation of Apple Group. The researcher adopted triangulation research design and obtain primary data through personal interview with Apple employees. Secondary data were also adopted to validate the position of the primary data. Findings indicated that Apple group adopts a flat and organic structure where authorities are centralized from the top down the ladder. As a result of the culture of internal secrecy, much of the organizational activities are not published. Though, the researcher did not consider the effect of organizational structure on responsibility accounting, it is obvious that without an organizational structure, decision-making organogram is not feasible.

Gadave (2017) examined the concept of responsibility accounting within the context of performance reporting. Using an exploratory research design, the researcher critically evaluated the concept of RA by identifying the reasons for its current wide spread adoption together with the basic requirements. The researcher concluded by identifying the various responsibility centres, management support and cost control through responsibility accounting. However, since the study is not empirical in nature, it failed to relate RA with any aspect of managerial function such as 
European Journal of Accounting, Auditing and Finance Research

Vol.8, No. 7, pp.80-96, July 2020

Published by ECRTD-UK

Print ISSN: 2053-4086(Print), Online ISSN: 2053-4094(Online)

planning, controlling, decision-making or performance evaluation. Zimnicki (2016) discussed extensively the rationale for RA being regarded as an inspiration for segment reporting. Based on literature analysis, the researcher traced the historical background of RA from the twentieth century to the period of centralization, decentralization and divisionalized structure. Responsibility centres was also classified into four major areas such as cost, revenue, profit and investment centres. Again, even though the analysis is detailed, it lacked empirical analysis to support any position.

Bai, Feng, Yue and Feng (2017) investigated the effect of the adopted organizational structure on the performances of a new product development team using cross-functional integration associated with the team as the intermediary variable. Using survey research design to obtain relevant data from the manufacturing and high technology industry in China. The result of the multilever linear model indicates that the specific features of an enterprise organogram significantly affect the development of new product. However, cross-sectional data was adopted for this research, the result from time series data is yet to be obtained and this represents a major gap in this research.

Efni (2017) investigated the mediating effect of investment decisions and financing decisions on the impact of corporate value. The population adopted was the property and real estate sectors quoted on the Indonesia stock exchange for a period of nine years from 2001-2008 using secondary data. Based on descriptive and inferential analysis, the study observed that only the investment decisions and the company's risk are the two variables that will increase the net worth of any company. On the other hand, financing decisions and dividend policy are not able to increase the market value. Even though, the study is limited to the real sector, effect of responsibility accounting on investment decisions were not considered.

Biswas (2017) embarked on comprehensive review of related literature on responsibility accounting adoption by different types of establishment. The study adopted a descriptive and exploratory design coupled with secondary data to analyze the associated benefits of implementing responsibility accounting system. Findings revealed a direct relationship between company activities and performance. In addition, the concept of responsibility accounting will facilitate effective control and managerial decisions including corporate investment decisions. The study is however, not empirical in nature and as such not directly related to any specific establishment or environment. Owino (2017) examined the adoption of the responsibility accounting concept among the various universities in Uganda considering agency relation. Using cross sectional survey design comprising of both qualitative and quantitative data to examine the hypothesis. Findings revealed that agency theory is significantly related to responsibility accounting concept and that appropriate authorities are obtained at the departmental levels before preparing the actual budget. This research work is restricted to the educational sector of the economy and may not be directly appropriate within the private sector even in the same environment. Tran (2017) investigated the adoption of responsibility accounting concept to sustainable development among the Vietnamese manufacturing firms. Based on the survey research design, with a sample size of 64 and using structured questionnaire as a research instrument to obtain relevant data from managers and head of department of textile and garment manufacturers. Based on the result provided by SPSS (22), findings revealed that the adoption of responsibility accounting is at 
European Journal of Accounting, Auditing and Finance Research

Vol.8, No. 7, pp.80-96, July 2020

Published by ECRTD-UK

Print ISSN: 2053-4086(Print), Online ISSN: 2053-4094(Online)

different stages and not necessarily at the same level. The study however, did not relate responsibility accounting with the corporate investment decision.

Rani and Rani (2015) stated that the size of any organization determines whether the structure of such should be centralized or decentralized along with defining responsibility accounting system, which is necessary in terms of delegation of responsibilities and authorities where the managers are made to be responsible for planning and controlling the business activities. They also added that, comparing each responsibility centre's standard data with actual data, organization's performance result can be either favourable or unfavourable. Allahverdi, (2014) observed that with the current development of business throughout the world, organizations need to adopt new technologies along with different strategies for the attainment of the organizational objectives. He opined that today's business must change its structure, with new methodology about the centrifugal administration in business where decision making authority is delegated from higher administration units to lower ones which leads to the increase in the importance of responsibility accounting in business.

Nyakuwanika et al.,(2012) conducted a study relating to an analysis of effective responsibility accounting system strategies in the Ministry of Health and Child Welfare (MOHCW) in Mashonaland West province of Zimbabwe with sample of 70 employees from fourteen stations using systematic and purposive sampling methods. The study observed that planning and control were not integrated among the departments and performance reports were not distributed among the sectional managers on a regular basis.

\section{Justification for the Study}

Generally, previous literature in finance and financial management provides evidence that corporate investment decisions are universally influenced by various factors among which are corporate risk and dividend (Efni, 2017), knowledge spillover level (Zheng \& Wang, 2018), financial statement analysis (Anaja \& Onoja 2015, Vestine, Kule\& Mbabazize, 2016)stock market valuation (Azarmi \& Schmidt, 2016), earnings management (Julio \& Yook, 2016), political uncertainty (Riem, 2016), cashflow sensitivity (Basty, 2016), interest rate (Ibi, Offiong \& Udofia, 2015), corporate governance (Bistrova, Lace \& Travonaviene, 2015), survival and replacement of worn-out assets (Pevic \& Durkin, 2015), macroeconomics and law-related factors (Bialowalski, \& Weziak-Bialowolski, 2014), capital structure (Arafat, Warokka \& Suryasaputra, 2014) but not on organizational structure. Thus, this study hopes to expand the frontier of knowledge by adopting quantitative measures in evaluating the effect of organizational structure on corporate investment decisions among selected listed manufacturing companies in Nigeria.

\section{METHODOLOGY}

The study adopted survey research design to obtain relevant data. Survey method was adopted to collect primary data from the respondents. Several researchers supported this approach based on the argument that people's intention is better measured via survey study and that causal or predictive relationships are better tested with survey (Bryman \& Bell 2001; Ogunbameru \& 
European Journal of Accounting, Auditing and Finance Research

Vol.8, No. 7, pp.80-96, July 2020

Published by ECRTD-UK

Print ISSN: 2053-4086(Print), Online ISSN: 2053-4094(Online)

Ogunbameru, 2010; Sanders, Lewis \& Thormhill, 2009). The study focused on manufacturing organizations registered and quoted by the Nigeria stock exchange (NSE). From the total population of fifty four (54) quoted manufacturing firms, a sample of thirty four (34) firms were purposively selected for data collection spread across five (5) industries comprising of conglomerates, consumer goods, health care, industrial goods and natural resources. The sampling frame comprises of the top management, members of the accounting and finance division together with respondents from the firm of external auditors. The study used quantitative approach by measuring respondents' view on a graduated scale for statistical analysis in order to have a reasonable and accurate measurement of the constructs rather than using observation. The questionnaire was sectionalized to reflect demographic information, independent and dependent variables. Responses were rated using the five-point Likert scale. Internal consistency (reliability test) was carried out on the research information using Cronbach Alpha reliability test, with the aid of Statistical Package for Social Sciences (SPSS) version 24. The result of the test shows coefficients ranging between 0.756 and 0.973 among the constructs. Given these results, it is concluded that the instrument is reliable and capable of producing consistent results. The associational statistics tested the correlation between the variables, while the inferential statistics was meant to test the hypotheses and consequently draw conclusions.

\section{Model Specifications}

For the use of primary data, the following models functions were developed $\mathrm{Y}=f(\mathrm{x})$

$\mathrm{y}=$ Dependent variable

$\mathrm{x}=$ Independent variable

$\mathrm{y}=$ Corporate Investment Decisions (CID)

$\mathrm{x}=$ Organizational Structure $(\mathrm{ORS})$

$\mathrm{CID}=f(\mathrm{ORS})$.

The long -run relation of Organizational structure and Corporate Investment Decision in Nigeria as stated in equation 1 is transformed into; the long run relationship of organizational structure and corporate investment decision in Nigeria is given in equation 3 as,

$\mathrm{CID}=\beta 0+\beta 10 R S+\mu$

The scale variable measures organizational structure and corporate investment decision. The measure of organizational structure and corporate investment decision using SPSS (Statistical Package for Social Sciences) version 24 approach. 
European Journal of Accounting, Auditing and Finance Research

Vol.8, No. 7, pp.80-96, July 2020

Published by ECRTD-UK

Print ISSN: 2053-4086(Print), Online ISSN: 2053-4094(Online)

\section{RESULT AND DISCUSSION}

\section{Presentation and Analysis of Result}

Table 4.1: Descriptive Result of Corporate Investment Decision and Organizational Structure (ORS)

\begin{tabular}{|lc|l|l|}
\hline Description & Mean & Standard Deviation \\
\hline $\begin{array}{l}\text { Corporate Investment } \\
\text { Decision (CID) }\end{array}$ & 4.06 & 0.60 \\
\hline $\begin{array}{l}\text { Organizational Structure } \\
(\text { ORS) }\end{array}$ & 4.13 & 0.53 \\
\hline
\end{tabular}

Source: Field Survey, 2019 Using SPSS Version 24.

The mean standard deviation results for Corporate Investment Decision (CID) are 4.06 and 0.60 respectively. On the average, the respondents agreed with the statement as representing the corporate investment decision in listed manufacturing firms in Nigeria with a mean of 4.06 and standard deviation of 0.60 . The implication of the respondents submission was that corporate investment decisions involve huge outlay of capital, over a long period of time together with an expectation of positive returns on the investment. The mean and standard deviation results for Organizational Structure (ORS) are 4.13 and 0.53 respectively. On average, the respondents agreed with the statement that organizational structure is a key component of management decisions among listed manufacturing firms in Nigeria. The implication is that a clearly defined organizational structure will be divided into administrative units according to the nature of the activity. Additionally, there is clarity in dividing the work among centre of responsibility and a specialized manager for each centre of responsibility with a mean of 4.13 and standard deviation of 0.53 .

\section{Correlation Coefficient}

Table 4.2: Correlation Coefficient

\begin{tabular}{|l|l|l|l|l|l|l|}
\hline Variables & Mean & S.D & N & r & P & Remark \\
\hline Corporate Investment Decision (\%) & 76.55 & 14.88 & 486 & & & \\
\hline Organizational structure (\%) & 78.16 & 13.26 & 486 & 0.60 & $<0.001$ & Sig \\
\hline
\end{tabular}

Source: Field Survey, 2019

Interpretation: Table 4.2 shows that corporate investment decisions is rated $76.55 \%(s d=$ $14.88 \%)$ and organizational structure is rated $78.16 \%(s d=13.26 \%)$. The correlation coefficient reveals that there is a strong positive and significant relationship between corporate investment decision and organizational structure in listed manufacturing firms in Nigeria $(r=0.60, p<0.05)$. This implies that the better the organizational structure in place, the better the corporate investment decision of listed manufacturing firms in Nigeria. 
European Journal of Accounting, Auditing and Finance Research

Vol.8, No. 7, pp.80-96, July 2020

Published by ECRTD-UK

Print ISSN: 2053-4086(Print), Online ISSN: 2053-4094(Online)

Table 4.3: Regression analysis of the relationship between organizational structure and corporate investment decision in listed manufacturing firms in Nigeria

\begin{tabular}{|l|l|l|l|l|l|l|l|}
\hline Model & B & $\begin{array}{l}\text { Std. } \\
\text { Error }\end{array}$ & $\mathbf{T}$ & Sig. & $\mathbf{R}^{\mathbf{2}}$ & Adj R $^{\mathbf{2}}$ & $\mathbf{F}_{\mathbf{1}, \mathbf{4 8 4}=}$ \\
\hline (Constant) & 23.887 & 3.233 & 7.389 & $<0.001$ & 0.361 & & $272.978 ;$ \\
\hline Organizational Structure & 0.674 & .041 & 16.522 & $<0.001$ & & 0.359 & $\mathrm{p}<0.001$ \\
\hline
\end{tabular}

Source: Field Survey, 2019

The regression model of the effect of organizational structure on corporate investment decision in listed manufacturing firms in Nigeria is given as:

$\mathrm{CID}=\beta_{0}+\beta_{1}$ ORS $+\mu$

CID $=23.887+0.674 *$ Organizational Structure

The results show that organizational structure has positive relationship with corporate investment decisions in listed manufacturing firms in Nigeria. In addition, there is evidence that organizational structure has significant relationship with corporate investment decisions of the selected listed manufacturing firms in Nigeria $(\mathrm{ORS}=0.674, t$-test $=16.522, \mathrm{p}<0.05)$. This implies that organizational structure is a significant factor influencing changes in corporate investment decisions of selected listed manufacturing firms in Nigeria. Concerning the magnitude of the estimated parameters, the coefficient is 0.674; this implies that an improvement in the organizational structure will lead to 0.674 increases in corporate investment decisions of the selected manufacturing firms in Nigeria. The $\mathrm{R}^{2}$ which measures the proportion of the changes in corporate investment decisions as a result of changes in the organizational structure explains about 36 per cent changes in corporate investment decisions of listed manufacturing firms in Nigeria, while the remaining 64 per cent were other factors explaining changes in corporate investment decisions of selected manufacturing firms in Nigeria but were not captured in the model. Therefore, the t-statistic of 16.522 is statistically significant with $p<0.05$ indicating that the null hypothesis that organizational structure does not have significant effect on corporate investment decisions in selected listed manufacturing firms in Nigeria was rejected. Thus, the alternative hypothesis that organizational structure has significant effect on corporate investment decisions in selected listed manufacturing firms in Nigeria was accepted at 5 per cent level of significance.

\section{DISCUSSION OF FINDINGS}

Finding from the descriptive analysis in Table 4.1 revealed that the adoption of an appropriate and well-designed organizational structure was high (mean $=4.13$ ). The finding on organizational structure being a key component of responsibility accounting was supported by studies like, Allahverdi (2014), Bai, Fang, Yue and Feng (2017), Gadave (2017), Quanyen and Yezhavang (2013) and Tasnim 2018. Policy implication of this finding is that the foundation of any decision making model depends largely on appropriate organizational structure. The study established the view that a strong and positive relationship exist between corporate investment decisions and organizational structure. Therefore, the better and appropriate the company's organizational structure, the better the corporate investment decisions. 
European Journal of Accounting, Auditing and Finance Research

Vol.8, No. 7, pp.80-96, July 2020

Published by ECRTD-UK

Print ISSN: 2053-4086(Print), Online ISSN: 2053-4094(Online)

\section{Implication of Findings}

The findings of this study have implications to both corporate and institutional investors, employees, government agencies, customers, lenders and creditors, regulators and researchers. The study has revealed that quantitative measurement used in this study have informed that appropriate organizational structure adoption has significant effect on corporate investment decisions in listed manufacturing companies in Nigeria. The findings informed the policy measures that can be taken by management and regulators in providing manufacturing companies with quality based information for the purpose of effective investment decision making.

Shareholders and prospective investors are provided with the information from this study, that a well-designed organogram are imperative for their decision making in terms of additional investment or new investment and the contribution of their businesses to different stakeholders. Employees are provided with information that specified those responsible for strategic, tactical and operational decisions. To the researchers, the study provides additional literature in the field of organizational structure and investment decisions. This work is arguably the first to examine the impact of organizational structure on corporate investment decision among the listed manufacturing companies in Nigeria. This position is premised on the fact that, organizational structure is far-reaching in terms of the information content. Additionally, such report will facilitate effective planning, control and performance evaluation apart from the corporate investment decisions.

\section{CONCLUSION AND RECOMMENDATION}

The study examined the effect of organizational structure on corporate investment decisions in listed manufacturing firms in Nigeria. The findings from the study provide relevant empirical evidence by showing that organizational structure have significant effects on corporate investment decisions. The implications of the effect of organizational structure adoption on corporate investment decisions were given statistical and empirical fundamentals considered useful for policy and strategy formulations. Therefore, the study concluded that organizational structure has strong, significant and positive effect on corporate investment decisions in listed manufacturing firms in Nigeria;

Based on the aforementioned findings, the study, recommends that top management of manufacturing firms should endeavor to establish or adopt an appropriate organizational structure based on their size, nature and complexities of operation. For effective operation, large manufacturing firms can be structured in one or two ways: functionally (all activities of a similar type within a company are placed under the control of appropriate departmental head) or divisionally (split into divisions in accordance with the products which are produced).Smaller manufacturing concern may adopt centralized structure by restricting delegation of decision making authority near the top of the organizational structure. For medium size establishments, decentralization of authority would be appropriate. This would involve the process of delegating decision making responsibility especially on a relatively permanent basis or the tendency to disperse decision-making authority in an organization structure. 
European Journal of Accounting, Auditing and Finance Research

Vol.8, No. 7, pp.80-96, July 2020

Published by ECRTD-UK

Print ISSN: 2053-4086(Print), Online ISSN: 2053-4094(Online)

\section{REFERENCES}

Abolaji, O. B. \& Adeolu, O. O. (2015). Perceived effects of international financial reporting standards (IFRS) adoption on quality financial reporting of quoted companies in Nigeria. Research Journal of Finance and Accounting, 6(23), 1-8.

Adeniji, A.A (2012). An Insight into Management Accounting (6 $6^{\text {th }}$ Edition) Lagos: Value Analysis Publishers

Adeniji, A.A (2018). Performance Management (4 ${ }^{\text {th }}$ Edition) Lagos: Value Analysis Publishers

Ahmed, A. S. \& Duellman, S. (2011). Evidence on the role of accounting conservatism in monitoring managers' investment decisions. Accounting and Finance, 51(3), 609-633.

Akembor, C. O. \& Nwaiwu, J. N (2013). The effectiveness of responsibility accounting in evaluating segment performance of manufacturing firms. KASU Journal of Accounting Research and Practice. 2(2), 103-112.

Akintoye, I.R. (2019). Accounting: A Mismanaged Concept Requiring Urgent Re-definition. $28^{\text {th }}$ Inaugural Lecture, Babcock University, Ilishan, Nigeria

Allahverdi, M. (2014). Centrifugal Administration and Responsibility Accounting System in Business. The Clute Institute International Academic Conference. Clute Institute, Munich, Germany 373-381

Anaja, B \& Onoja, E.E. (2015). The Role of financial statement on investment decision making: A case of UBA Plc. (2004-2013). European Journal of Business, Economics and Accountancy 3(2), 12 -37

Arafat , M.Y., Warokka, A. \& Suryasaputra, R. (2014). Capital structure and investment decision: what does emerging consumer goods industry tells us? Journal of financial studies \& Research, 1-11

Arya, A., Glover, J., \& Radhakrishman, S. (1998). The Controllability Principle in Responsibility Accounting. Another look: Retrieved from http://wenku.baidu.com/view

Atu, O. O. K., Ogbeide, E., Agbo, I. S. \& Ozele, C. E. (2014). Responsibility Accounting: An Overview. IOSR Journal of Business and Management. 16(1), 73-79.

Azarmi, T. \& Schmidt (2016). Determinants of Corporate Investments: Theory and Evidence on the Investment Effect of Corporate Taxes. Accounting and Business Research, 46(7), 731759.

Bai, W., Feng, Y.,Yue, U., \& Feng, L. (2017). Organizational structure, cross-functional integrations and performance of new product development team. $13^{\text {th }}$ Global congress on manufacturing and management procedia Engineering 17(4) 621-629

Baker, C.R. (2003). Theoretical Approaches to MICS, in proceeding of the Annual Conference of the Administrative Sciences of Association of Canada Critical Accounting Research Track, edited by Normal Macintosh, 25(3), 283-299.

Bakre, O.M. (2007). The Unethical Practices of Accountants and Auditors and the Compromising Stance of Professional Bodies in the Corporate Nigeria: Accounting Forum, 31(3), 277303.

Basty, N. (2016). Corporate investment and cashflow sensitivity: Evidence from a Jasmin revolution period in Tunisia market. Asian economic and financial review. 6(11), 634-646 
European Journal of Accounting, Auditing and Finance Research

Vol.8, No. 7, pp.80-96, July 2020

Published by ECRTD-UK

Print ISSN: 2053-4086(Print), Online ISSN: 2053-4094(Online)

Bialowolski, P. \& Weziak-Bialowolska, D. (2014). External factors affecting investment decisions of companies. Economics: The Open-Access, Open-Assessment E-Journal, 8 (1),1-21.

Bistrova, J., Lace, N. \& Tvaronaviciene, M. (2015). Corporate governance as a factor for investment decision making on CEE equity markets. The 15th world multi-conference on systemics, cybernetics and informatics proceedings. 1, 59-64.

Biswas, T. (2017). Responsibility Accounting: A review of related literature. International Journal of Multidisciplinary Research and Development. 4(8), 202-206.

Budiarso, N. S., Mandey, S. L. \& Karamoy, H. (2018). Testing of agency and stewardship theories on financial accountability in Sulawesi region, Indonesia. International Journal of Finance and Accounting, 7(1), 13-18.

CBN (1997). Financial Sector Distress in CBN Briefs. Research Department, 97(1), 12.

Chan-Jane, L., Tawei, W. \& Chae-Jung, P. (2015). Financial reporting quality and investment decisions for family firms. Asia Pacific Journal of Management, 1(1), 1-34.

Chidiebere, M. E. (2013). Reliance on published financial statements and investment decision making in the Nigeria banking sector. European Journal of Accounting Auditing and Finance Research, 1(4), 67-82.

Ciao-Wei, C., Collings, W.D., Kravet, T. D. \& Mergenthaler, R. D. (2018). Financial statement comparability and the efficiency of acquisition decisions. Contemporary Accounting Research, 34(4), 1299-1310.

Demiski, J.S. \& Sappington, D.E. (1989). Hierarchal Structure and Responsibility Accounting.

Journal of Accounting Research. 27(1), 40-51.

Don, R.H., \& Marynne, M.M. (2005). Management Accounting. McGraw-Hill Companies. Inc. Drury, C. (1996). Management and Cost Accounting (4 ${ }^{\text {th }}$ Edition) International Thomson Business

Press London.

Ebhodaghe, J.U. (1996). Distress Management and Prevention Strategies for the Nigerian Banking System. NDIC Quarterly, 6(3), 19-36.

Efni, Y. (2017). The mediating effect of investment decisions and financing decisions on the effect of corporate risk and dividend policy against corporate value. Investment Management and Financial Innovations. 14(2), 27-37.

Eisenhardt, K.M. (1989). Agency Theory: An Assessment and Review. The Academy of Management Review, 14(1), 57-74.

Enoma, A. \& Mustapha, I. (2010). Factor analysis of investment decision in Nigerian insurance companies. Interdisciplinary Journal of Contemporary Research in Business, 2(8), 108120.

Fakir, A. N. M. A., Islam, M. Z \& Miah M. S. (2014). The use of responsibility accounting in garments industry in Bangladesh. Journal of business studies. 1(2), 1-15.

Freeman, R. E (2011). Some thoughts on the development of stakeholder theory. In R. Phillips (Ed.) Stakeholder Theory: 25 Years Later, 212-233. Cheltenham, UK: Edward Elgar Publishing.

Gadave, B. R. (2017). Glimpses on Responsibility Accounting and Reporting. Imperial Journal of Interdisciplinary Research (IJIR). 3(2); 22-28 
European Journal of Accounting, Auditing and Finance Research

Vol.8, No. 7, pp.80-96, July 2020

Published by ECRTD-UK

Print ISSN: 2053-4086(Print), Online ISSN: 2053-4094(Online)

Gharayba, F., Debi, M., \& Nasar, A. (2011). The extent of applying the elements of responsibility accounting in the industrial shareholding companies and its effect on the company's profitability and operational efficiency. Administrative Sciences. 38(1), 219-234.

Healy, P. M \& Palepu, G. K. (2003).The fall on Enron. Journal of Economic Perspectives, 17(2), 3-26.

Ifeanyi, D. (2011). Corporate Governance and Bank Failure in Nigeria: Issues, Challenges and Opportunities. Research Journal of Finance and Accounting, 2(2), 1-18.

Jagongo, A. \& Mutswenje, V. S. (2014). A survey of the factors influencing investment decisions: The case of individual investors at the NSE. International Journal of Humanities and Social Science. 4, 92-102.

Jensen, M. C. \& Meckling, W. H. (1976). Theory of the firm: Managerial behavior, agency costs, and ownership structure. Journal of Financial Economics, 3(4), 305-360.

Kermit, D.L. \& Barbara, C. (1996). Fundamental Accounting Principles (14 ${ }^{\text {th }}$ Edition) Chicago, IL: Richard Irwin Time Mirror Higher Education Group.

Maduenyi, S., Oke, A. O. \& Ajagbe, M. A. (2015). Impact of organizational structure on organizational performance. International conference on African development issues: social and economic models for development track.354-358

Martinelli, P.D. (2001). System Hierarchies and management systems. Research and Behavioural Science, 18 (1) 68-82

Mitnick, B. M. (1975). The theory of agency: The policing paradox and regulatory behavior.

Public Choice (Winter), 24(1), 27-42.

Mojgan, S. (2012). Examining the role of responsibility accounting in organizational structure. American Academic \& Scholarly Research Journal. 4(5), 12-22

Okoye, E.I. \& Alao, B.B. (2008). The Ethics of creative Accounting in financial reporting: The challenges of Regulatory Agencies in Nigeria. Accountants of Nigeria 16(1) 22-32

Omokhudu, O. O. \& Ibadin, O. P. (2015). The value relevance of accounting information: evidence from Nigeria. International Journal of Finance and Accounting, 5(3), 165-176.

Pajrok, A. (2014). Responsible accounting in the hospitality industry. Journal of Education Culture and Society. 1(2); 53-60.

Parnell J. \& Wright, P. (1993). Generic Strategy and Performance: An Empirical Test of the Miles and Snow Typology British Journal of Management, 1(1); 29-36.

Pevic, M. \& Durkin, J. (2015). Determinants of investment decisions in a crisis: perspective of Croatians small firms. Management, 20(1), 115-133.

Quanagyen, T. \& Yezhuang, T. (2013). Organizational structure Influencing factors and impact on a firm. American Journal of Industrial and Business Management, 3 (1) 229- 23

Rani, R. \& Rani, M. (2015).The role of responsibility accounting in organizational structure, international journal of science, technology and management. 41(1), 185-190.

Riem, M. (2016).Corporate investment decisions under political uncertainty. Ifo Working Paper, No. 221, Leibniz Institute for Economic Research at the University of Munich, Munich.

Ritika, M. R. (2015). The role of responsibility accounting in organizational structure. International Journal of Science, Technology and Management, 4(1), 185-190.

Shilpa, G. (2014). Responsibility Accounting practices in India. 2nd International Conference on Multidisciplinary Research \& Practice. 3(1), 373-378. 
European Journal of Accounting, Auditing and Finance Research

Vol.8, No. 7, pp.80-96, July 2020

Published by ECRTD-UK

Print ISSN: 2053-4086(Print), Online ISSN: 2053-4094(Online)

Sungun, G. (2015). Capital investment decisions in small and medium sized enterprises in Turkey. European Journal of Accounting, Auditing and Finance Research. 3(1), 46-55.

Tasnim, M. (2018). An Organizational Analysis on Apple European Journal of Business and Management 10 (11), 22-30

Thomas S.A. \& Ramaswamy R. (1996). Matching Managers to Strategy: Further Tests of Miles and Snow Typology British Journal Management, 7(1), 247-261.

Tran, T. T. (2017). Application Responsibility Accounting to Sustainable Development in

Vietnam Manufacturers: An Empirical Study. Economics World. 5(6), 573-583.

Valipour, H \& Moradbeygi, M. (2011). Corporate debt financing and earning quality. Journal of Applied finance \& Banking, 1(3), 139- 15

Venazi, D. (2012). Financial performance measures and value creation. Journal of Art 1(1), 9 13.

Vestine, M., Kule, J. W., \& Mbabazize, M. (2016). Effect of financial statement analysis on investment decision making. A case of bank of Kigali. European Journal of Business and Social Sciences. 1 (5), 279-303.

Williams, S.M., Ho, W.P., \& Carol, A. (1999). Corporate Social Disclosures by Listed Companies on their Web-sites: A International Comparison. The International Journal of Accounting, Elsevier, 34(3), 389-419.

Zarnowitz, V. (1992). Rational Expectations and Macroeconomic Forecasts. In Zarnowitz. V. Ied.), Business Cycles: Theory, History, Indicators, and Forecasting, 1(1), 462-491)

Zheng, J. \& Wang, Y. (2018). Research on Knowledge Resources Investment Decisions in Cooperated New Product Development. Journal of Service Science and Management, 11(1), 101-115.

Zimnicki, T. (2016). Responsibility accounting inspiration for segment reporting. Copernican Journal of Finance \& Accounting, 5(2), 219-232. 